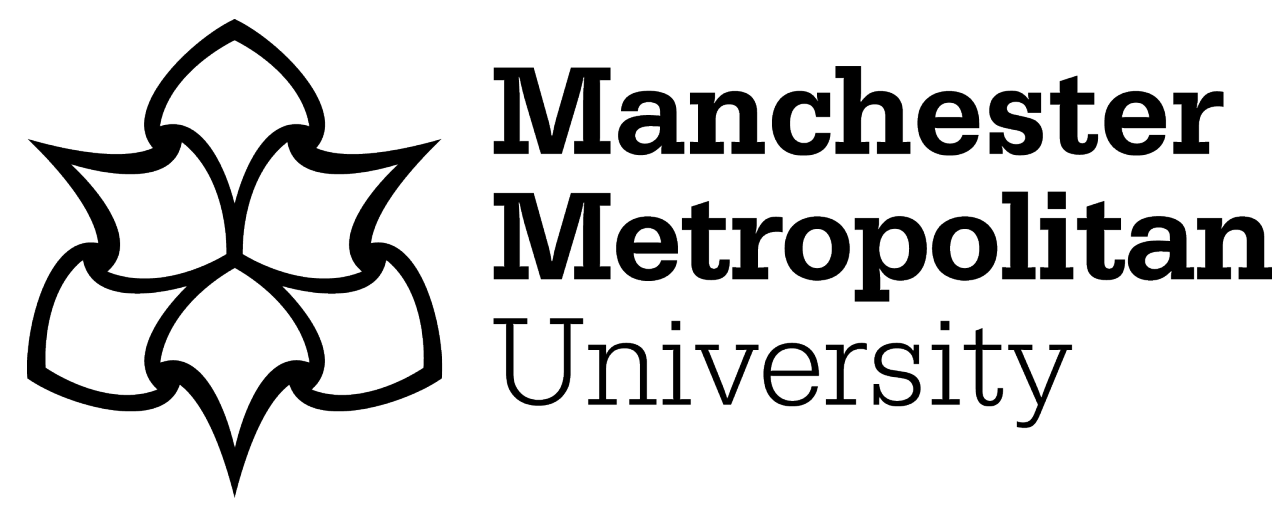

Pickard, Sarah, Bowman, Benjamin ORCID logoORCID: https://orcid.org/0000-0003-2866-1612 and Arya, Dena (2020) "We Are Radical In Our Kindness": The Political Socialisation, Motivations, Demands and Protest Actions of Young Environmental Activists in Britain. Youth and Globalization, 2 (2). pp. 251-280.

Downloaded from: https://e-space.mmu.ac.uk/627103/

Version: Accepted Version

Publisher: Brill

DOI: https://doi.org/10.1163/25895745-02020007

Please cite the published version 
"We Are Radical In Our Kindness": The Political Socialisation, Motivations, Demands and Protest Actions of Young Environmental Activists in Britain

\author{
Sarah Pickard \\ Senior Lecturer and Researcher, Université Sorbonne Nouvelle, Paris, France \\ sarah.pickard@sorbonne-nouvelle.fr
}

Benjamin Bowman

Lecturer, Manchester Metropolitan University, Manchester, England, UK

B.Bowman@mmu.ac.uk

Dena Arya

PhD Candidate, Nottingham Trent University, Nottingham, England, UK

dena.arya2019@my.ntu.ac.uk

\begin{abstract}
The year 2018 was a watershed in environmental activism, especially regarding young activists. Greta Thunberg started her School Strikes for Climate and the environmental movement Extinction Rebellion was founded. This article deals with young people's involvement in these two global movements. It draws on 60 semi-structured interviews carried out with young environmental activists before, during and after protest actions under the auspices of the climate strikes and/or Extinction Rebellion in five British locations.

The particularities of the political socialisation of this young generation is outlined and how it contributes to young people becoming environmental activists. The article then identifies the the "radical" demands made by young environmental activists and their "radical" repertoire of contention in relation to their perceptions of the "radical" compared to hegemonic definitions. The interviews show that young environmentalists constitute a generation of activists this is committed to obtaining significant change from powerholders through the use of deliberately non-violent direct action that challenges academic perceptions of radical repertoires of contention.
\end{abstract}

\title{
Keywords
}

young people, political socialisation, youth protest, environmental activism, radical protest, social movements, non-violent direction action

version finale 17-09-2020 


\section{"We Are Radical In Our Kindness": The Political Socialisation, Motivations, Demands and Protest Actions of Young Environmental Activists in Britain}

\section{Introduction}

Young people's environmental activism has a long history (Bajracharya, 1994; Järvikoski, 1995; Stephens 1996; O’Brien et al. 2018). Since 2018, youth involvement in environmental protests has been the subject of much attention. In August 2018, in Sweden, Greta Thunberg, when aged 15, started her school climate strike outside Parliament (Thunberg, 2019a, p. 25-28) that developed into the Fridays for Future movement involving school pupils and other young people around the world (Bowman, 2019, 2020; Collin and Matthews, 2021; Holmberg and Alvinius, 2019; Wahlström et al., 2019). Also, in 2018, in October, activists in Britain from the protest group RisingUp! ${ }^{1}$ launched the environmental network Extinction Rebellion (XR), which has since become an international and intergenerational movement. ${ }^{2}$

Young environmental activists have been 'doing' peaceful protest actions in an attempt to make their voices heard so that politicians and corporations 'do' something urgent and effective about the degradation of the environment (Arya, Bowman and Pickard, 2019; Pickard, 2019a, 2019b; Bowman 2020; Pickard, Bowman and Arya, 2021). As well as calling for significant evolutions within existing political and economic systems, there are young people who aim to disrupt those systems and contribute to systemic change (O'Brien et al. 2018). Young environmental activists' demands do not operate within the bounds of existing systems and at times their dissent can be considered radical in the traditional academic definition.

Both the school climate strikes and Extinction Rebellion have mobilised young people in nonelectoral forms of political participation that go beyond individual acts of engagement (such as adopting a plant-based diet) and established collective acts of contestation (such as attending a rally). Young people have been protesting deliberately using non-violent direct action (NVDA), including civil disobedience. They have been employing tools and actions from a wide "repertoire of contention," i.e. "the whole set of means [a group] has for making claims of different kinds on different individuals or groups" (Tilly, 1986, p. 4). However, here young environmental activists' usage of the term "radical" in relation to their protest actions does not always equate with traditional academic usage of the term.

This article deals with the young people's environmental activism in Britain drawing on our interviews with school climate strikers and Extinction Rebellion activists. We set the voices of these young environmental activists within the historical context of youth-supported activism and environmental protest in Britain and the wider global movement. Drawing on theoretical work in political sociology and youth studies, we explore the political socialisation, the motivations, the demands and the repertoire of contention employed by young environmental activists in relation to their political subjectivities. In particular, we investigate why young people are taking part in environmental protests and what these young environmental activists said about "radical" demands and "radical" protest actions. We report on how the term "radical" was used explicitly and implicitly by the young environmental activists themselves. This means on the one hand, their demands for extreme, fundamental, major changes from governments and economic entities (ways political and economic systems function, structural and systemic change, and policy change), and on the other hand, their choice to use peaceful non-violent forms of direct action to protest within a collective horizontal movement, i.e. in the words of one young Extinction Rebellion protester camping out in Trafalgar Square: 
"We are radical in our kindness. We are breaking social norms. We are a radical community" (Skylab, 19, XR activist, London, Oct. 2019).

First, the article outlines the methodology for this study. It then provides the background to the period in which this young generation has been and is being politically socialised in Britain and more widely, which contributes to them being mobilised as environmental activists within movements using non-violent direct action. Next, the article examines the "radical" demands made by young environmental activists and their "radical" repertoire of contention in relation to their perceptions of the "radical."

\section{Methodology}

This article is based on interviews we carried out with young environmental activists involved in the school climate strikes and/or Extinction Rebellion in Britain. We interviewed young protesters between the ages of 11 and 34, i.e. from young people starting secondary school through to those leaving young adulthood. This deliberately wide age-range covers when most young people are starting to be politically socialised (and taking part in school climate strikes) through the transition to independent adulthood that has been extended largely due to precarity (Furlong, 2013, 2017). A majority of participants were taking part in a protest but were not involved at an organisational level. A minority were founding members of local Extinction Rebellion groups and core organisers for local climate strikes. Sixty young environmental activists took part usually on their own, in semi-structured interviews with one or two of the authors, lasting between fifteen minutes and one hour. ${ }^{3}$ The interviews were carried out before, during and after protest actions at five sites in Britain: (a) Edinburgh, (b) London, (c) Manchester, (d) Nottingham and (e) Sheffield, in September and October 2019.

This period was marked by two key protest events. First, the international school climate strike as part of the "Global Week for Future," from 20 to 27 September 2019. Organisers claimed it mobilised "six million people" (Emilsson et al., 2020) with the main strike taking place on Friday 20 September 2019 involving "two million people walking out of schools and workplaces" across the world, according to Fridays For Future. In Britain, more than 200 climate school strike rallies took place, notably in Birmingham, Brighton, Bristol, Cambridge, Edinburgh, Glasgow, London, Manchester, Nottingham and Oxford. It was the "biggest-ever climate protest" (Taylor and Watts, 2019) that "saw over 300,000 people take to the streets across the UK," according to the UK Student Climate Network (UKSCN, 2019), which coorganised the day of action. Second, the autumn or October "International Rebellion" fortnight initiated by Extinction Rebellion from 7 to 19 October 2019. Extinction Rebellion and "allied movements" planned to "gather in major cities across the globe" to "continue to rebel against the world's governments" in a "global uprising," in order to obtain "system change not climate change" (Extinction Rebellion, 2019b). There were two-weeks of manifestations across Britain with the focus of actions being in London, especially the Westminster area around the Houses of Parliament. The campaign is said to have drawn " 30,000 activists" to the capital (Townsend, 2019). The political socialisation of young environmental activists that contributed to them being there is discussed in the next section.

\section{The Political Socialisation of the Young Generation: a Mobilising Force for Environmental Activism}

Young people in Britain and in other democracies have been and are being politically socialised at a specific time in history. We posit this sets them apart from older generations and binds them together as a generational unit (Mannheim, 1952), as part of a political generation (Grasso, 
2016, 2017; Grasso et al, 2017). It has had an impact on the values of the current generation of young people, as well as how they view politicians, politics and polity (representative democracy). This influences how they 'do' (electoral and non-electoral) politics, formulate demands and express dissent, characterised by non-violent direct action and Do-It-Ourselves (DIO) political participation (Pickard, 2019a). In this section, we outline the political and economic background to young people's lives since the beginning of the twenty-first century (when our oldest participants turned 14) marked by the global financial crisis of 2008 (when our youngest participants were born) and their environmental activism.

In many countries, the current young generation has been and is being politically socialised during a time of successive and overlapping crises (including political, economic, financial, social, constitutional and environmental crises) (Muxel, 2010, 2019; Pickard and Bessant, 2017; Tiberj, 2017) and now the COVID-19 crisis, which has amplified many young people's fears for their futures (Reicher and Stott, 2020; Beatfreeks, 2020). Young people have been particularly affected by these crises (Verick, 2010; Horton, 2016), especially the ongoing crisis of austerity (Bramall, 2013; della Porta, 2015; Henn et al., 2018), during which their lives are lived in precarity (Bessant, Farthing and Watts, 2017) and socio-economic injustices, in multiple spheres, such as education, employment, housing, health and leisure (Howker and Malik, 2013; Sukarieh and Tannock, 2015). ${ }^{4}$

In Britain, the young generation has witnessed and/or taken part in an accumulation of youthled and youth supported protest actions about a variety of youth-centred and wider policies coalescing around opposition to capitalism and austerity measures (Cairns, et al., 2016; Farnsworth and Irving, 2015). They have lived in the era that includes school strikes against the Iraq War (Cunningham and Lavalette, 2004), student protests against the withdrawal of the Education Maintenance Allowance (EMA), cuts to higher education funding, the tripling of university tuition fees and growing student debt (Power, 2012), the unrest (sometimes known as riots) in English cities in 2011 (Bowman, 2014) and anti-capitalism Occupy London protests (Saunders, Roth and Olcese, 2015), as well as protest actions against Brexit. The increase in protest actions in Britain form part of a global cycle of protest moving around the world since the global financial crisis of 2008 about similar grievances and injustices, with similar demands and repertoire of contention (Castells, 2015; Giugni and Grasso, 2019), in a bid to have a fairer and kinder world.

These circumstances have contributed to sentiments of scepticism towards democratic institutions and opposition to political elites, often perceived to be corrupt and colluding (della Porta, 2013a). It has been widely reported that there has been a growing sense of mistrust, distrust, disappointment, disillusionment and disgust regarding elected politicians and representative democracy more widely, especially among young people (European Social Survey, 2018; Hansard Society, 2019; Harrison, 2019), including those not old enough to vote. As one school climate striker commented:

\footnotetext{
"We are not adults but you know, we have thinking brains and we can rationalise and yes maybe we haven't got as much experience but, perhaps, we can see things that adults maybe couldn't, because we can see it for what it is and it's less tainted with desires for power and money" (Isla, 16, climate strike activist, Edinburgh, Sep. 2019).
}

At the same time, there is a growing insistence on the breakdown of the intergenerational contract and that older generations, especially powerholders, have failed the young generation. This point is often underlined by Greta Thunberg, for example, when she addressed the United Nations Climate Action Summit on 23 September 2019: "You are failing us. But the young 
people are starting to understand your betrayal. The eyes of all future generations are upon you" (Thunberg, 2019b) and expressed by one of the climate strikers we interviewed as follows:

“My parents aren't exactly too happy about all of this. So it's kind of, every night after everyone's gone to bed I'd get [my protest sign] out and do a little bit [...] They don't quite understand the importance of what we're doing here today" (Nora, over 16 but exact age not provided, climate strike activist, Manchester, Sep. 2019).

The current young generation is characterised by a greater proportion entering further and higher education associated with greater rates of political participation for diverse reasons including civic skills, political knowledge and social networks (Persson, 2015). Moreover, youth today has greater and wider access to digital technologies and information in a globalised world than previous generations, which increases political participation (Boulianne and Theocharis, 2018). Many of the digitally connected young environmental activists we interviewed said that had become aware of the climate crisis via social media (due to sharing and algorithms), rather than the mainstream media.

Academics specialising in young people's political participation have observed, through quantitative and qualitative analyses, a shift in values among the young generation (especially among those entering post-obligatory education and young women), which sets them apart from older generations and previous generations of young people. Sloam and Henn (2019) call them "young cosmopolitans." They appear to have more socially liberal values, are more "open" and are more attached to "post-materialist values" (Inglehart, 1977, 1997; Norris and Inglehart, 2019).

The shift in values plays a role in making the young generation have a growing awareness of and sensitivity to environmental issues (Wolf and Moser, 2011). Indeed, in surveys and polls, 18 to 24-year-olds stated it was the second most important concern (after Brexit) prior to the 2019 general election and they did so more than older age cohorts (see for example, YouGov, 2019).

Environmental justice is an approach to environmentalism that foregrounds "concepts like autonomy, self-determination, access to resources, fairness and justice, and civil and human rights" (Taylor, 2000b, p. 534). It is, therefore, a broadly intersectional approach, recognising environmental damage within "a system of interlocking oppressions" (Roberts, 2012, p. 240), including the legacies of colonialism, global inequalities in contemporary capitalism, structural racism, and so forth. As Sloam (2020) points out: "it is almost impossible - and counterproductive - to disentangle social, economic and environmental issues."

We contend that being attached to "post-materialist values" does not prevent the young generation living in precarity from having concern for materialist values (Tiberj, 2017; Pickard, 2019a). Moreover, environmental justice that is often presented uniquely as a "post-materialist" value can also be considered a materialist concern. Interviewees in Britain expressed concern for the very materialist consequences of climate change across the world, especially in the Global South (see also Bessant, Mejia Mesinas and Pickard, 2021).

Thus, in the two first decades of the twenty-first century, we contend young people in Britain have been politically socialised during a time of precarity and digital connectivity that has made them especially likely to be disappointed in elected politicians and other powerholders, including parents, more exposed to youth-led and youth-supported protest and more likely to be attached to certain values. We proffer also that the current young generation is therefore 
more likely to be concerned about the environment, more likely to use their agency to make demands of power holders and more likely to take part in peaceful environmental activism within movements and networks (in contrast to traditional hierarchical political structures) on the specific issue of environmental justice.

This is examined in more depth in the next sections, in relation to what young environmental activists consider to be their "radical" demands and "radical" repertoire of protest action, by reporting more on what they told us in interviews.

\section{The "Radical" Demands of Young Environmental Activists}

The particular context of the political socialisation of young people since the start of the twentyfirst century in Britain has made them likely to be sensitive to and receptive to environmental issues. As well as the political, economic and social contexts, in our interviews with school climate strikers and Extinction Rebellion protesters, we identified five main intertwining factors contributing to their mobilisation and what they consider to be their "radical" demands for environmental justice. ${ }^{5}$

(i) Both the Extinction Rebellion and the school for climate strike movement have formulated and continue to express "demands" for significant change from powerholders. Extinction Rebellion's original "three key demands" were:

(a) The government must tell the truth by declaring a climate and ecological emergency, working with other institutions to communicate the urgency for change.

(b) The government must act now to halt biodiversity loss and reduce greenhouse-gas emissions to net zero by 2025 .

(c) The government must create and be led by the decisions of a Citizens' Assembly on climate and ecological justice (Extinction Rebellion, 2019a, p. 11).

Ahead of the World Economic Forum summit in Davos, Switzerland in 2020, a list of demands were made of world leaders, authored by members of the Fridays for Future school climate strike movement, including Greta Thunberg, as follows:

\footnotetext{
"We demand that at this year's forum, participants from all companies, banks, institutions and governments immediately halt all investments in fossil fuel exploration and extraction, immediately end all fossil fuel subsidies and immediately and completely divest from fossil fuels. We don't want these things done by 2050, 2030 or even 2021, we want this done now - as in right now" (Thunberg, et al., 2020, emphasis in original).
}

It is noteworthy that these various demands were often mentioned by the young environmental activists we interviewed and the urgent need for their implementation.

(ii) The urgency and scale of the "environmental crisis," also referred to as the "environmental crisis," "ecological crisis" and "climate crisis" is depicted in apocalyptic and catastrophic discourse within environment movements. For example, to quote Greta Thunberg again, this time during her "Our House is on Fire" speech at the World Economic Forum, Davos, on 25 January 2019:

\footnotetext{
"We are facing a disaster of unspoken suffering for enormous amounts of people. [...] There are no grey areas when it comes to survival. Now we all have a choice. We can create transformational action that will safeguard the living conditions for future generations. Or we can continue with our business as usual and fail" (Thunberg, 2019a, pp. 21-22).
} 
Similarly, in the handbook This is Not A Drill published by Extinction Rebellion (2019a), we read:

"The science is clear: we are in the sixth mass extinction event and we will face catastrophe if we do not at swiftly and robustly" (Extinction Rebellion, 2019a, p. 1).

This has had an impact on young people and their sentiments regarding the need to act swiftly:

"I've got a feeling that we humans are not really good for the planet [...] but if we really want to keep on staying here, and if we really want our children to have a great time on this earth, then we really need to change our behaviour now" (Sarah, 24, climate strike activist, Edinburgh, Sep. 2019).

And to make what some young environmental activists described as "radical" demands and change:

"In my dream [I want], radical system change. I want the climate emergency to be so high the political agenda, across the political spectrum, that no party can get away with not doing anything. [...] My current obsession is 'we are unstoppable, another world is possible.' It does not have to be like this way. We just need to live differently" (Rosie, 25, XR activist, London, Oct. 2019).

"Extinction Rebellion is radical because it is going against the status quo, because we are asking for things the government does not want to happen. We are having to make it radical. It is not usual. It is not in line with what society expects. [...] I hope for political and systemic change for a more sustainable future. For change, we need to stop how were currently functioning [...]" (Becky, 32, XR activist, London, Oct. 2019).

Becky's hope "for political and systemic change for a more sustainable future" is an appropriate illustration of the characteristic vision of the young activists who were interviewed in the study. The vision is not just in favour of votes for environmentalist parties, nor for technocratic adjustments to carbon emissions policies. Nor is it even for radical changes to policies. Rather, the vision for a radical rebuilding of systems and for the construction of a new world. Rhetorical constructs like "another world," as in Rosie's quote, and "systemic change," in Becky's are common because these young people's concept of "radical" is specifically in search of a new, fairer, kinder and sustainable world.

(iii) The emergency and magnitude of the climate crises and how it is expressed in the school climate strikes and Extinction Rebellion movements engender strong emotions. For example, participants spoke of sadness, feeling grief for the planet and being in mourning:

"I think the way to deal with the heaviness is just to do something that's rather than just lie in bed and think 'I can't sleep everyone is going to die!'. Like you are going to die anyway at some point .... But you can make things better before that, I think" (Amy, 21, climate strike activist, Nottingham, Sep. 2019)

These powerful emotions contribute to young environmental activists making what they consider to be "radical" demands of powerholders. ${ }^{6}$

(iv) The (perceived and real) inertia, inefficacy, "youth gloss," and "youth-bait" (Pickard, 2019a), "cool-hunting" (Farthing, 2010, p. 184), lip service and greenwashing from political parties and politicians (and, sometimes, adults in general) about climate change influence young people's opinions of the political elite. These strong feelings also encourage them to become environmental activists and make demands for "radical" change from powerholders:

"I looked into what was happening. It made me scared. And then I realised the government wasn't doing anything and it made me angry" (Mitch, 20, XR activist, London, Oct. 2019). 
(v) In this way, young people are turning away from the hierarchical structures of traditional political parties and "(un)representative democracy." They are keen to take action within more fluid, leaderless, horizontal (political) networks and movements purporting to have internal democracy and to operate direct democracy (Saunders, 2013). This fits with "a long-term cultural trend toward horizontal, noninstitutional movements" (Tufekchi, 2014, p. 203).

The young environmental activists we interviewed were obviously emotional about the issues at stake and the need for change due to the scale and urgency of the "climate crisis." This was reflected in their demands, generally those expressed by the Fridays For Future and Extinction Rebellion. They considered their demands to "radical" because they require "radical" change from the world they have always known. What is striking in those demands is the hope for a more honest, more democratic, less capitalist, fairer and kinder world, i.e. a healthier planet than the one they have inherited from older generations. In order to make their demands heard and acted upon, they are using peaceful protest actions, as examined in the next section.

\section{The "Radical" Repertoire of Contention and Protest Actions of Young Environmental Activists}

In terms of repertoire of contention: "the ways that people act together in pursuit of shared interests" (Tilly, 1995, p. 41) used by young environmental activists, in interviews, we observed four main reasons why they very deliberately choose non-violent direct action and their perceptions of it being "radical."

(i) Due to the emergency and scale of the climate crisis (reflected in the demands expressed by young environmental activists), climate school strikers and Extinction Rebellion activists frequently commented that just adapting their personal daily habits were not enough, i.e. individual lifestyle politics. Lifestyle politics is when daily habits and choices are influenced by political convictions often related to "sustainable citizenship" (Stolle, Micheletti and Berlin, 2012). Young people have become particularly associated with ethical consumption and political consumerism (Stolle, Kyroglou and Henn, 2017; Hooghe and Micheletti, 2018; Kyroglou and Henn, 2020), such as boycotting and buycotting, recycling and having a plantbased diet or being a vegan (for an overview see Pickard, 2019a). Young environmental activists said that individual acts of electoral and non-electoral political participation through the ballot box and personal or individual acts - lifestyle politics - are no longer sufficient:

"People have gone vegan, written to their MP, stopped flying. They have been doing that for decades. It has not changed anything. There have been some successes, but they have not really changed anything. [...] Direct action is more effective" (Polly, 16, climate strike and XR activist, Sheffield, Oct. 2019).

Many participants claimed that in order to deal with the climate emergency, individual acts (of lifestyle politics) are no longer or not enough to bring about change:

"I feel like, it was just something I could do. It sometimes feels like there isn't a lot you could/can do to change something and, you know, you can do your own individual things like recycling, not buying loads of plastic, turning the lights off. But I suppose going down to Parliament is sort of making a point and you can be one that adds up to big numbers. So, that's something you can do." (Isla, 16, climate strike activist, Edinburgh, Sep. 2019).

Thus, they believed to bring about changes it was necessary to participate collectively using non-violent direct action that they considered "radical." 
The repertoire used by participants in school climate strikes, involves pupils walking out of school to rallies and marches usually with self-made placards. Participants spoke of the courage it took to stand up and leave a classroom often on their own and in many cases without school authorisation leading to an unauthorised absence:

"It was an unauthorised absence ... I said it was important ... Would you rather that we knew how to like to calculate the area of a tunnel or that the world was healthy and we were all healthy and happy?" (Corrie, 14, climate strike activist, Edinburgh, Sep. 2019).

They talked about how breaking the school rules they had been brought up to respect felt "radical." 7

As for the protest actions used by Extinction Rebellion activists in Britain, they are harnessing and adapting forms of direct action that have been in the repertoire of contention since the civil rights movement of the $1960 \mathrm{~s}$, such as occupations of public spaces. They are building on an established repertoire of environmental protest actions used in the 1970s and 1990s (Doherty and Paterson, 2000; Seel, Paterson and Doherty, 2000), by "deep green" ecologists in the 1970s, for example, EarthFirst! (Wall, 1999), by anti-road building and other environmental activists in the 1990s that reached a peak in the mid-1990s (Rootes, 2003, see also Rootes, 1997, 2000), the Reclaim the Streets alternative globalisation movement in late 1990s (Saunders, 2013) and then by anti-fracking (shale extraction) protesters in the 2010s (Jackson, Gilmore and Monk, 2018; Jackson, et al., 2019; Muncie 2019). ${ }^{8}$

However, the environmental protests mentioned above mostly entailed occupations and civil disobedience over a sustained periods (weeks and months), such as tree-top protests (activists living for weeks in trees that were to be cut down for a road to be built). They also included tunnelling (digging under areas designated for road-building and living in those tunnels, especially at eviction times, as well as lock-ons (for example, being padlocked to a piece of industrial machinery). Moreover, some carried out criminal damage ("monkeywrenching") to private equipment and property, i.e. "ecotage" (for overview, see Pickard, 2020). According to Rootes (2003, p. 51), the "most physically audacious forms of action" were carried out by "young protesters" (Rootes, 2003, p. 51), dubbed "ecowarriors." Nevertheless, the numbers of young people involved were much smaller than the current environmental movement. ${ }^{9}$ The longevity of occupations and occasional use of physical force - predominantly used against inanimate objects like machinery - differentiates the repertoire of contention in the past from that used by most young Extinction Rebellion activists that advocate vehemently non-violent direct action.

One form of "physically audacious" action, i.e. using physical force, which remains characteristic of young Extinction Rebellion action (although not of the climate strikes) is the use of force by occupying protesters against their own bodies, in the form of restraints against removal. Such occupations typically occur in public spaces and, to a lesser extent, private spaces. Occupations are held over a limited time - typically a day, or up to a fortnight in the case of the International Rebellion in October 2019. Supergluing (to a building, bridge, transport) is also a "signature" of Extinction Rebellion protests, as are lock-ons and swarming (blocking traffic for seven minutes). There is a whole range of peaceful protest actions that are about creativity and performance, which range from stencilling, graffiti and street art to die-ins (groups of activists lying down in a public place representing the extinction of species, etc.). Well known XR actions in public spaces have also included funeral processions and the "Red army"'(dressed in donated scraps of red material and with white face paint they walk around silently in groups drawing public attention). Another example of a public space Extinction 
Rebellion action was in Westminster, London, on 3 October 2019, when thousands of litres of fake blood (water and red food dye) were sprayed from a fire-engine bearing the words "FUNDING CLIMATE DEATH" onto the Treasury. It is significant that most of these involve civil disobedience and can entail the activist being arrested (see below).

For Tilly $(1995$, p. 7$)$ "the word repertoire helps describe what happens by identifying a limited set of routines that are learned, shared, and acted out through a relatively deliberative process of choice." The repertoire of contention used by Extinction Rebellion clearly fits this description - the movement provides materials and guidelines online and at events. The forms of direct action being used have been used by other protest movements in the past in Britain and elsewhere. In this way, today's young (and older) environmental activists are building on and adapting existing protest repertoires that require greater personal engagement and commitment (time, health, safety) than simply attending a rally on a Saturday, but less than the radical "ecowarriors" mentioned above.

(ii) Young participants often expressed the wish to depart from the hitherto established way of doing protests, in favour of a more "disruptive" ways. Disruptive has two meanings that can both be applied to the demands and direct-action repertoires of the contemporary global wave of environmental protest. First, disruptive means new, original, innovative and ground-breaking that stops things from continuing as usual and changes or reconfigures traditional ways and the status quo. Second, disruptive means to cause upset and disorder, i.e. to act within the existing system but aiming to change the way it works (O'Brien et al, 2018).

Our young interviewees affirmed (both explicitly and implicitly) that they felt it was necessary to act and to "be a nuisance" to the general public, the police and politicians and "do" "disruptive" or "radical" protest actions (that were more imaginative and creative than traditional methods) and together, in order to obtain "radical" change from power-holders about the "environmental crisis.":

"Disruption draws media attention. Disruption forces action on institutions, so that they have to take action" (George, 21, XR activist, Sheffield, Oct. 2019).

(iii) Many young environmentalists underlined the importance for them of being non-violent and peaceful in their protest; they made a link between environmental justice, social justice, respect for nature and humanity, as part of a "radical community" "radical" in its "kindness" (Skylab, 19, XR activist, London, Oct. 2019). Skye (20) who was camping in Trafalgar Square as part of the Extinction Rebellion October 2019 "International Rebellion" mentioned how important it was for her to be wearing a patch saying: "We Act In Peace."

This very deliberate endeavour for peaceful protest reflects literature from Extinction Rebellion and school for climate strikes. Leaflets and flyers handed out in London during the Extinction Rebellion 'International Rebellion' fortnight stated:

\footnotetext{
"WE ACT IN PEACE."

"THE REBEL AGREEMENT.

All Rebels are asked to follow our basic agreements. They provide a basis for trust so that both Rebels and the public know what we can expect from each other.

- We show respect to everyone - to each other, the general public and to the government and police.

- We engage in no violence, physical or verbal, and carry no weapons.

- We hold ourselves accountable for our actions and do not hide from the legal consequences.

- We bring no alcohol or illegal drugs.

- We take responsibility for ourselves; we are all crew.
} 
We are here together until the Government acts on our three demands for necessary action on the climate and ecological emergency. This code aims to help us attract the many people we need to make this movement effective."

(iv) Peaceful collective protest can operate as a counterbalance to a host of negative emotions surrounding the issues at stake and the perceived violence and urgency of the situation. The use of non-violence was described as the opposite to corporate violence:

"With non-violent direct action, no individual is harmed. But multinationals cause violence every day" (George, 21, XR activist, Sheffield, Oct. 2019).

But they also considered it to be in opposition to certain policing tactics (see below). Furthermore, many participants described doing/performing creative and artistic non-violent protest actions with like-minded young people as an uplifting and joyful experience:

"This is actually a painting that I did months ago, just kind of supporting people doing good things, rather than just painting pictures of famous icons and stuff. I wanted to start making the point of celebrating people that were doing something good... It is Greta, I think she's doing amazing things and she's out there, the way everyone should be" (Claire, 31, climate strike activist, carrying a large painting of Greta Thunberg, Manchester, Sep. 2019).

(v) Collective protest actions that are disruptive and/or radical are an effective means with which to draw media attention and sensitise the general public to the issues at stake. Activists viewed them as a better or the only way to make politicians and corporations aware of the issues, in order to bring about top-down action on the "ecological breakdown" from policy makers and economic leaders:

\footnotetext{
"We've known about climate change for ages. I've signed petitions and been involved in local advocacy groups. Nothing has changed. So, we have to change tactics. [...] Disruption draws media attention. [...] Disruption forces action on institutions, so that they have to take action" (George, 21, XR activist, Sheffield, Oct. 2019).

"We have tried to lobby politicians and the government. But is hasn't worked. So we have to take to the streets. [...] We want to create a situation where the government have to act." (Becky, 32, XR activist, London, Oct. 2019).
}

Carrying out acts of protests involving civil disobedience in order to get arrested is a key tactic within Extinction Rebellion's repertoire of contention: "One of the most powerful ways to bring about change is when people are willing to be imprisoned for non-violent direct action" (Griffiths, 2019, p. 96). The rationale is that when the police make arrests it takes up police time and resources. ${ }^{10}$ Being arrested requires a particular level of commitment from activists and can be dangerous. During Non-Violent Direct Action (NVDA) training sessions held by Extinction Rebellion (during protest actions and at other times), we observed that the implications and what to deal if arrested were clearly explained in detail. The Extinction Rebellion protest action of being an "arrestable," i.e. willing to be arrested was considered by our interviewees a "radical" tactic and more "radical" than other methods used in protests:

"I suppose getting yourself arrested is quite radical... Compared to other movements... Taking control of public spaces seems radical to me. It is a bit more radical that what you'd expect from the British public" (Curtis, 21, XR activist, London, Oct. 2019).

Young Extinction Rebellion protesters also talked about how getting arrested was not an essential part of being an activist, reflecting claims from the movement's literature: 
"XR USES NON-VIOLENT CIVIL DISOBEDIENCE to demand action by the Government on mass extinction and to minimise the risk of social collapse through climate breakdown. [...] There is a role for you in XR regardless of whether you are willing to be arrested, but the thrust of our movement is about getting people onto the streets to directly challenge government power structures $[\ldots]$. ."

Many interviewees went on to say that getting arrested could hinder their futures, especially regarding employment within an enhanced Disclosure and Barring Service (DBS) check carried out by a potential employer. We observed a cognitive dissonance between wanting to be a fully committed Extinction Rebellion activist and the risks involved. This was especially the case regarding the possibility of not being able to do good and "kind" things for the planet and society in a future career (for example, as engineer or a teacher among those interviewed):

"There are other ways of being valuable, other ways of being a hero. If I get arrested it will stop me getting a job" (Ollie, 21, XR activist, Sheffield, Sep. 2019).

"I might want to be a teacher and I can't get arrested. But I want to help out by adding to the numbers here" (Tom, 29, XR activist, London, Oct. 2019).

They also expressed fears regarding the difficulty with a criminal record of finding any job that was already difficult due to precarity of the young generation growing up in austerity Britain (see above).

We noted how the radical tactic of being an "arrestable" pulled young Extinction Rebellion environmental activists in different directions and the reasons given for not being an "arrestable" could be interpreted as a form self-justification but also a reason or excuse to fellow activists. Clearly, there was a lot at stake for the young generation that differentiates them from older activists for whom being arrested posed less of a problem. Moreover, some of the founding members of Extinction Rebellion - who are older long-term activists - advocate being arrested as a crucial tactic within Extinction Rebellion, and have been arrested several times, including Ian Bray, Gail Bradbrook and Roger Hallam. ${ }^{11}$

Roger Hallam (54), after spending six weeks in Wormwood Scrubs prison in 2019, wrote in an Extinction Rebellion Facebook post that "going to prison is [...] the single biggest act of radical political and nonviolent effectiveness any social movement can decide upon. [...] dramatic action is so necessary" (Hallam, 2019, October 26).

This stance does not acknowledge the privilege involved in such acts, in particular when taking into account the potential consequences for younger, non-white or less affluent members of the environmental movement. This position can also run the risk of discounting and drawing attention away from peaceful protest, as well as alienating young potential protesters. The "radicalisation" of Extinction Rebellion tactics in relation to young people was made more complex by the XR "Global Hunger Strikes for People and Planet UK" started in November 2019.

How young environmental activists, within and outside of Extinction Rebellion, perceive the tactic of arrest and the inequalities and privileges that play a part in such radical action are an area for further empirical investigation.

The demands and tactics used by Greta Thunberg and especially Extinction Rebellion are considered radical and dangerous by certain authorities. On 14 October 2019, the London Metropolitan Police Service (MPS) placed a banning order on Extinction Rebellion using Section 14 of the Public Order Act 1986. It meant that the environmental network would no 
longer be able legally to carry out any protest actions in the capital and remain within the law. Tents pitched in Trafalgar Square were taken down and the site cleared by police officers. However, the High Court overturned the police decision in November 2019 qualifying it as unlawful. In November 2019, Extinction Rebellion featured in "anti-radicalisation material" (with jihadist and far-right groups), specifically about young Extinction Rebellion activists that were alluded to in a Prevent counter-terrorism document in relation to young people (Dodd and Grierson, 2020). Then, in January 2020, Extinction Rebellion was described as a "key threat" in an operations assessment of counterterrorism carried out by the City of London police force (Grierson and Scott, 2020). The important issue of social control and repression of protest movements cannot be examined in detail here (see Power, 2012; Pickard, 2019b). However, the policing of mostly peaceful environmental protest and official assertion that it is "radical" are crucial with regard to democratic protest - the right to protest - how young people think about police and protesting.

\section{Conclusion}

The question of what is "radical" in terms of political action is contested in academic literature. The kernel of shared meaning among definitions of radical political action is that most scholars agree the radical seeks to break or rupture an established order, often a political, social or economic order. In contemporary environmental activism, especially climate change activism, what is "radical" is also a "radical democratic politics" towards climate change, forming around a "robust logic of resistance" (Kakenmaster, 2019). This is indeed reflected in the demands made by the young environmental activists we interviewed and their own view of it.

Academic literature struggles to define the radical because of the connotations of violence sometimes carried by the word, especially when phrased as "radicalisation," a term most often used in studies of political violence which "generally correspond to the successive swells of violence that in many ways define modern society" (della Porta and Haupt, 2012).

The young environmentalists we interviewed often considered their demands to be "radical" calling for "radical change" in accordance with traditional academic usage of the term. However, they tended to take care when describing their protest actions as "radical." Typically, if young activists used the term "radical" to describe their actions they also developed the term with descriptors like radical "in our kindness" or radical "but not violent":

"What we do is radically non-violent" (Oliver, 28, XR activist, London, Oct. 2019).

Or they uttered similar constructions that indicated a but distanced themselves from militant, violent radicalism. Emilija's comment is typical in that she considers the protest actions to be radical "in a good way":

"[XR] in a good way it is radical ... not in a bad sense. It is radical because it is not comfortable for society. With science we need radical change. It is radical as society can reflect on how much change we need to do. And I don't know we can achieve change if it is not radical' (Emilija, 20, XR activist, London, Oct. 2019).

To date, the care young environmental activists are taking is not always reflected in the ways various authorities portray them (Bessant, 2020). The findings of our study would support the authorities in continued negotiation and cooperation with young environmental activists, who were taking democratic action while upholding a spirit of cooperation, kindness and responsibility for others. 
Our findings are in line with previous scholars who argue that radical environmentalists "have generally, except in a very few extreme cases [...] vehemently condemned" violence against living beings (Fletcher, 2018). Foran expresses the evolution in radical repertoires of contention that favour non-violent direct action in relation to the current environmental activism:

\footnotetext{
"In the $21^{\text {st }}$ century, the movements for radical social change (a term more apt for this century's great social movements than revolution) has itself changed, as activists, reformers, dreamers, and revolutionaries globally have increasingly pursued non-violent paths to a better world, intending to live and act as they would like that world to be. That is, the ends of justice are no longer held to justify the means of violence, but the means of non-violent resistance reflect and guarantee the ends they seek. In this way, them embody and illustrate the virtues of prefigurative politics and in particular horizonalist ways to realise them" (Foran, 2019, p. 112).
}

In this way, the current young generation of environmental activists are not "radical" in the traditional sense of using violence (used by certain young environmental activists in the past and some of the founders of Extinction Rebellion today and in other movements elsewhere in the world), whereby "the means justify the ends." But they are "radical in their kindness." We posit that the demands for social justice and non-violent protest actions of this generation of young people are a deliberately peaceful reaction to perceived and real violence against them by certain politicians, media outlets and policing strategies. Protesting in peace is part of their personal and collective identities; it is an integral part of living in harmony with their values and hopes when faced to hostile world.

Young environmental activists are also building on the existing repertoire of contention and expanding it collectively, making them more disruptive and creative, in response to frustration with the perceived inefficacy of other forms of action and a perceived need for wide reaching changes to an entrenched social, political and economic system. This is "Do-It-Ourselves political participation" or "DIO politics" (Pickard, 2019a, 2019c), whereby young people are taking politics into their own hands together, in order to bring about change from politicians.

In this article, we have shown that the political socialisation of the young generation in Britain has occurred during a time of austerity and precarity, which has affected them in particular, as well as a shift in political values. We have identified seven interlinked triggers that motivate young environmental activists in their demands and protest actions that they consider "radical":

(a) Environment movements making radical demands.

(b) Ecological and environmental emergency: the perception that activists are living in a moment of crisis.

(c) Ecological anxiety: negative emotions of fear, dread, anxiety and mourning, often strongly felt.

(d) Failure of institutional politics: the perceived inertia of, and inefficacy of political elites.

(d) Need to "do something" to make powerholders "do something" radical.

(e) Attraction of horizontalism and fluid political networks promoting internal democracy.

(f) Ineffectiveness and/or insufficiency of lifestyle politics compared to collective actions.

(g) Efficacy of "disruptive" protest action.

(h) Joyful solidarity: positive emotions arising from collective action, shared spaces, and activities. 
(i) Raised awareness: the perceived need to capture media attention, to sensitize the general public and to draw elites into action.

(j) Importance of carrying out peaceful and non-violent direct action.

Within the context of globalisation and a largely youth-led (and largely youth-supported) global wave of environmental protests, the implications are important for future electoral and nonelectoral political participation of this young generation, as well as governmental and corporate action on the environment.

Only a minority of young people in Britain have been involved in school climate strikes and/or Extinction Rebellion protests, which do not only include young people. We do not know enough about the numbers and types of young people involved in environmental activism beyond popular claims that there are mainly white, middle-class (and privileged). We do not have data on numbers and proportions so we do not know enough about them. We cannot measure the impact in terms of sensitivity to the subject. But we do know they are sensitising other young people and older people, including politicians. Indeed, in the words of Polly:

"In the short term, students and youths have been striking ... they have created a massive change about climate breakdown. We have changed how people think about it and how they talk about it" (Polly, 16, climate strike and XR activist).

Youth mobilisation about the "environmental crisis" continues apace around the world and it involves greater numbers of young people than in past decades over a now sustained period. In our study, we show that the young environmental activists engaged in the Fridays For Future and Extinction Rebellion movements are mostly living in precarious circumstances. They show commitment to continued "radical" demands in the academic sense of the term. They show dedication to what they consider "radical" peaceful protest actions rooted in their concept of kindness: interconnected approaches to human endeavour, which is different to most traditional and hegemonic academic definitions of radical regarding language and actions in the repertoire of contention.

The current young generation of young environmental activists feel frustrated at a time when they consider it critical for governments, corporations and individuals to act, but at a time when they also perceive inaction, experience austerity and their political actions are not always taken seriously. But they also feel supported by their peers and hopeful about the potential for their movement to make a difference in a resolutely peaceful and kind way as part of a generational movement. 


\section{Reference list}

Arya, D., Bowman, B and Pickard, S. (2019). Young Climate Strikers are Neither Immature Nor Ill-informed. London School of Economics - LSE Politics and Policy Blog, October 21. (https://blogs.lse.ac.uk/politicsandpolicy/britains-young-climate-strikers)

Bajracharya, D. (1994). Primary Environmental Care for Sustainable Livelihood: A UNICEF Perspective. Childhood 2 (1-2), pp. 41-55.

Bessant, J., Farthing, R. and Watts, R. (2017). The Precarious Generation: A Political Economy of Young People. London and New York: Routledge.

Bessant, J. (2020). Making Up Young People: Youth, Truth and Politics. London and New York: Routledge.

Bessant, J., Mejia Mesinas, A. and Pickard, S. (forthcoming 2021). Introductory essays. In: J. Bessant, A. Mejia Mesinas and S. Pickard, eds. 3 Volumes When Students Protest: Washington: Rowman and Littlefield.

Beatfreeks. (2020). A National Youth Trends Report Understanding The Impact of Coronavirus on Young People in the UK. National Youth Trends Take the Temperature. (https://www.beatfreeksyouthtrends.com)

Boulianne, S. and Theocharis, Y. (2018). Young People, Digital Media, and Engagement: A Meta-Analysis of Research. Social Science Computer Review 38 (2), pp. 111-127.

Bowman, B. (2014). 2011: Young Rioters and Imagined Revolution in the British Utopia of Calm. Postcolonial Studies 17 (1), pp. 90-103.

Bowman, B. (2019). Imagining Future Worlds alongside Young Climate Activists: A New Framework for Research. Fennia: International Journal of Geography 197 (2), pp. 295305.

Bowman, B. (2020). 'They Don't Quite Understand The Importance Of What We're Doing Today': The Young People's Climate Strikes As Subaltern Activism. Sustainable Earth.

Bramall, R. (2013). The Cultural Politics of Austerity: Past and Present in Austere Times. London: Palgrave Macmillan.

British Broadcasting Corporation (BBC). (2019). Extinction Rebellion: High Court Rules London Protest Ban Unlawful. BBC News Online. November 6. (https://www.bbc.com/news/uk-50316561)

Brown, W. (2011). Occupy Wall Street: Return of a Repressed Res-Publica. Theory and Event 14 (1).

Cairns, D., de Almeida Alves, N., Alexandre, A., and Correia, A. (2016). Youth Unemployment and Job Precariousness: Political Participation in the Austerity Era. London: Palgrave Macmillan.

Carter, N. (2018). The Politics of the Environment: Ideas, Activism, Policy. Cambridge: Cambridge University Press. Third edition.

Castells, M. (2015). Networks of Outrage and Hope: Social Movements in the Internet Age. Cambridge: Polity Press. Second edition.

Collin, P. and Matthews, I. (2021). School Strike For Climate: Australian Students Renegotiating Citizenship. In: J. Bessant, A. Mejia Mesinas and S. Pickard, eds, When Students Protest. Maryland: Rowman and Littlefield.

Cooper, V. and Whyte, D. (2017). The Violence of Austerity. London: Pluto Press.

Cunningham, S. and Lavalette, M. (2004). 'Active Citizens' or 'Irresponsible Truants'? School Student Strikes against the War. Critical Social Policy 24 (2), pp. 255-269.

Cushion, S. (2004). Misrepresenting Youth: UK Media and Anti-Iraq War Protesters. Bad Subjects: Political Education for Everyday Life. Series Cultural Front (65), pp. 18-20.

Cushion, S. (2007). Protesting their Apathy? An Analysis of British Press Coverage of Young Anti-Iraq War Protesters. Journal of Youth Studies 10 (4), pp. 419-437. 
della Porta, D. (2013a). Can Democracy be Saved? Participation, Deliberation and Social Movements. Cambridge: Polity Press.

della Porta, D. (2013b). Repertoires of Contention. Wiley Online Library (https://doi.org/10.1002/9780470674871.wbespm178)

della Porta, D. (2015). Social Movements in Times of Austerity: Bringing Capitalism back into Protest Analysis. Bristol: Polity Press.

Dobson, A. (2000). Green Political Thought. New York and London: Routledge. Third edition.

Dodd, V. and Grierson, J. (2020). Terrorism Police List Extinction Rebellion as Extremist Ideology. The Guardian. January 10. (https://www.theguardian.com/uknews/2020/jan/10/xr-extinction-rebellion-listed-extremist-ideology-police-preventscheme-guidance)

Doherty, B. and Paterson, M., eds. (2000). Direct Action in British Environmentalism. London and New York: Routledge.

Ehsan, R and Sloam, J. (2020). Resources, Values, Identity: Young Cosmopolitans and the Referendum on British Membership of the European Union, Parliamentary Affairs 73 (1), pp. 46-65.

Emilsson, K., Johansson, H. and Wennerhag, M. (2020) Frame Disputes or Frame Consensus? 'Environment' or 'Welfare' First Amongst Climate Strike Protesters. Sustainability 12 (3), pp. 882-902.

European Social Survey. (2018). (http://www.europeansocialsurvey.org).

Extinction Rebellion (2019a). This is Not a Drill. An Extinction Rebellion Handbook. London: Penguin.

Extinction Rebellion. (2019b). Extinction Rebellion website. (https://rebellion.earth).

Extinction Rebellion. (2019c). XR Global Hunger Strike. 'Event.' Extinction Rebellion website. 18 November. (https://rebellion.earth/event/global-hunger-strike).

Extinction Rebellion. (2019d). Extinction Rebellion to begin Global Climate Hunger Strikes in 22 countries. 'News.' Extinction Rebellion website. November 14. (https://rebellion.earth/2019/11/14/monday-18-november-extinction-rebellion-to-beginglobal-climate-hunger-strikes-in-22-countries).

Farnsworth, K. and Irving, Z. (2015). Social Policy in Times of Austerity: Global Economic Crisis and the New Politics of Welfare. Bristol: Policy Press.

Farthing, R. (2010). The Politics of Youthful Antipolitics: Representing the 'Issue' of Youth Participation in Politics. Journal of Youth Studies 13 (2), pp. 181-195.

Foran, J. (2019). Manifesto for a Sociology of Climate Change. In: KK Bhavnani, J. Foran, P Kurian and D Munshi, eds. Climate Futures. Reimagining Global Climate Justice. New York: Zed Books, pp. 105-113.

Furlong, A. (2013). Youth Studies. An Introduction. London: Routledge.

Furlong, A. (2017). Routledge Handbook of Youth and Young Adulthood. London: Routledge. Second edition.

Giugni, M. and Grasso, M. (2019). Street Citizens: Protest Politics and Social Movement Activism in the Age of Globalization. Cambridge: Cambridge University Press.

Grasso, M. (2016). Generations, Political Participation and Social Change in Western Europe. London and New York: Routledge.

Grasso, M. (2017). Young People's Political Participation in Europe in Times of Crisis. In: S. Pickard and J. Bessant, eds., Young People Re-Generating Politics in Times of Crises. London: Palgrave Macmillan, pp. 179-196.

Grasso, M., Farrall, S., Hay, C., Gray, E. and Jennings, W. (2017). Thatcher's Children, Blair's Babies, Political Socialisation and Trickle-down Value Change. An Age, Period and Cohort analysis. British Journal of Political Science (41) 2. 
Grierson, J. and Scott, R. (2020). Extinction Rebellion Listed as 'Key Threat' by Counter-terror Police. The Guardian. 19 January. (https://www.theguardian.com/environment/2020/jan/19/extinction-rebellion-listed-askey-threat-by-counter-terror-police).

Griffiths, J. (2019). Courting Arrest. In: Extinction Rebellion, eds. This is Not a Drill. An Extinction Rebellion Handbook. London: Penguin, pp. 95-98.

Hallam, R. (2019). Common Sense for the Twenty-First Century. Only Nonviolent Rebellion Can Now Stop Climate Breakdown and Social Collapse. (https://www.rogerhallam.com/wp-content/uploads/2019/08/Common-Sense-for-the21st-Century_by-Roger-Hallam-Download-version.pdf).

Hallam, R. (2019). I'm Out of Prison! Extinction Rebellion Facebook. 26 October. (https://www.facebook.com/roger.hallam.7/posts/2659331887521111)

Hansard Society. (2019). Audit of Political Engagement 16. The 2019 Report. The annual health check on attitudes towards politics in Great Britain. (https://www.hansardsociety.org.uk/publications/reports/audit-of-political-engagement16).

Harrison, S. (2019). Hostility Barometer 4. Electoral Psychology Observatory (London School of Economics) and Opinium. 19 November.

Henn, M., Oldfield, B. and Hart, J. (2018). Postmaterialism and Young People's Political Participation in a Time of Austerity: Postmaterialism. The British Journal of Sociology 69 (3), pp. 712-737.

Holmberg, A. and Alvinius, A. (2019). Children's Protest in Relation to the Climate Emergency: A Qualitative Study on a New Form of Resistance Promoting Political And Social Change. Childhood 27 (1), pp. 78-92.

Horton, J. (2016). Anticipating Service Withdrawal: Young People in Spaces of Neoliberalisation, Austerity and Economic Crisis. Transactions of the Institute of British Geographers 41 (4), pp. 349-362.

Howker, E. and Malik, S. (2013). Jilted Generation: How Britain Bankrupted Its Youth. London: Icon Books. Second edition.

Inglehart, R. (1997). Modernization and Postmodernization: Cultural, Economic, and Political Change in 43 Societies. Princeton: Princeton University Press.

Inglehart, R. (1977). The Silent Revolution: Changing Values And Political Styles Among Western Publics. Princeton: Princeton University Press.

Intergovernmental Panel on Climate Change (IPCC). (2018). Special Report: Global Warming of $1.5^{\circ} \mathrm{C}$. United Nations. (https://report.ipcc.ch/sr15/pdf/sr15_spm_final.pdf).

Jackson, W., Gilmore, J. and Monk, H. (2018). Policing Unacceptable Protest in England and Wales: A Case Study Of The Policing Of Anti-fracking Protests. Critical Social Policy 39 (1), pp. 23-43.

Jackson, W., Monk, H., Gilmore, J. and Short, D. (2019). Protesters' Experiences of Policing at Anti-fracking Protests in England, 2016-2019: A National Study. Liverpool: The Centre for the Study of Crime, Criminalisation and Social Exclusion, Liverpool John Moores University (LJMU).

Järvikoski, T. (1995). Young People as Actors in the Environmental Movement. Young 3 (3), pp. 80-93.

Kakenmaster, W. (2019). Articulating Resistance: Agonism, Radical Democracy and Climate Change Activism. Millennium: Journal of International Studies 47 (3), pp. 373-397.

Kyroglou, G. and Henn, M. (2017). Political Consumerism as a Neoliberal Response to Youth Political Disengagement. Societies (7) 4. 
Kyroglou, G. and Henn, M. (2020). Pulled In and Pushed Out of Politics: The Impact of Neoliberalism on Young People's Differing Political Consumerist Motivations in the UK and Greece. International Political Science Review.

Mannheim, K. (1952). The Problem of Generations. In: P. Kecskemeti, ed., Essays on the Sociology of Knowledge. London and New York: Routledge and Kegan Paul, pp. 276320.

Micheletti, M., Stolle, D. and Berlin, D. (2012). Habits of Sustainable Citizenship: The Example of Political Consumerism. In: A. Warde and D. Sotherton, eds. The Habits of Consumption. University of Helsinki, Helsinki Collegium for Advanced Studies.

Muncie, E. (2019). 'Peaceful Protesters' and 'Dangerous Criminals': The Framing and Reframing of Anti-fracking Activists in the UK. Social Movement Studies 19 (4), pp. 464 481.

Muxel, A. (2010). Avoir 20 and en politique. Les enfants du désenchantement. Paris: Éditions du Seuil.

Muxel, A. (2018). Politiquement Jeune. La Tour d'Aigues: Éditions de l'Aube.

Norris, P. and Inglehart. (2019). Cultural backlash: Trump, Brexit, and authoritarian populism. Cambridge: Cambridge University Press.

O'Brien, K., Selboe, E. and Hayward, B. M. (2018). Exploring Youth Activism on Climate Change: Dutiful, Disruptive, and Dangerous Dissent. Ecology and Society 23 (3), pp. 42.

Persson, M. (2015). Education and Political Participation. British Journal of Political Science 45 (3), pp. 689-703.

Pickard, S. (2019a). Politics, Protest and Young People: Political Participation and Dissent in $21^{\text {st }}$ Century Britain. London: Palgrave Macmillan.

Pickard, S. (2019b). Excessive Force, Coercive Policing and Criminalisation of Dissent: Repressing Young People's Protest in Twenty-first Century Britain. Revista Internacional de Sociología 77 (4).

Pickard, S. (2019c). Young Environmental Activists Doing It Themselves. Political Studies Association (PSA), Political Insight 10 (4), pp. 4-7.

Pickard, S. (2020). The Nature of Environmental Activism among Young People in Britain in the Twenty-first Century. In: B. Prendiville and D. Haigron, eds. Political Ecology and Environmentalism in Britain. Cambridge Scholars, pp. 89-109.

Pickard, S. and Bessant, J., eds. (2017). Young People Re-Generating Politics in Times of Crises. London: Palgrave Macmillan.

Pickard, S., Bowman, B. and Arya, D. (forthcoming 2021). Youth and Environmental Activism. In M. Giugni and M. Grasso, eds. Routledge Handbook of Environmental Movements. London and New York: Routledge.

Power, N. (2012) Dangerous Subjects: UK Students and the Criminalization of Protest. South Atlantic Quarterly 111 (2), pp. 412-420.

Reicher, S. and Stott, (2020). On order and Disorder during the COVID-19 Pandemic. British Journal of Psychology 59 (3), pp. 694-702.

RisingUp! (https://risingup.org.uk)

Roberts, D. E. (2012). Race, Gender, and the Political Conflation of Biological and Social Issues. Du Bois Review: Social Science Research on Race 9 (1), pp. 235-244.

Rootes, C. (2000). Environmental Protest in Britain 1988-1997. In: B. Seel, M. Paterson and B. Doherty, eds. Direct Action in British Environmentalism. London and New York: Routledge, pp. 25-61.

Rootes. C. (2003). Britain. In: C. Rootes, ed., Environmental Protest in Western Europe. Oxford: Oxford University Press, pp. 20-58.

Rootes. C., ed. (1997). Environmental Movements. London and New York: Routledge. 
Saunders, C. (2013). Environmental Networks and Social Movement Theory. London: Bloomsbury.

Saunders, C., Roth, S. and Olcese, C. (2015). Anti-Cuts Protests in the UK: Are We Really All in This Together? In: M. Giugni and M. Grasso, eds. Austerity and Protest. Farnham: Ashgate, pp. 171-190.

Seel, B., Paterson, M. and Doherty, B., eds. (2000). Direct Action in British Environmentalism. London and New York: Routledge.

Sloam, J. (2020). Young Londoners, Sustainability and Everyday Politics: The Framing of Environmental Issues in a Global City. Sustainable Earth 3 (14).

Sloam, J. and Henn, M. (2019). Youthquake: The Rise of Young Cosmopolitans in Britain. London: Palgrave Macmillan.

Stephens, S. (1996). Reflections on Environmental Justice: Children as Victims and Actors. Social Justice 4 (66), pp. 62-86.

Stolle, D., Hooghe, M., and Micheletti, M. (2018). Politics in the Supermarket: Political Consumerism as a Form of Political Participation. International Political Science Review 26 (3), pp. 245-269.

Sukarieh, M. and Tannock, S. (2015). Youth Rising? The Politics of Youth and the Global Economy. London and New York: Routledge.

Tarrow. S. (1998). Power in Movement: Social Movements and Contentious Politics. Cambridge: Cambridge University Press.

Taylor, D. (2000a). Meeting the Challenge of Wild Land Recreation Management: Demographic Shifts and Social Inequality. Journal of Leisure Research 32 (1), pp. 171179.

Taylor, D. E. (2000b). The Rise of the Environmental Justice Paradigm: Injustice Framing and the Social Construction of Environmental Discourses. American Behavioral Scientist 43 (4), pp. 508-580.

Taylor, M. and Watts, J. (2019). 'Enough is Enough': Biggest-ever Climate Protest Sweeps UK. The Guardian. September 20.

Theocharis, Y. and van Deth, J. (2018). Political Participation in the Changing World. London and New York: Routledge.

Thunberg, G. (2019a). No One is Too Small to Make a Difference. London: Penguin.

Thunberg, G. (2019b). Thunberg's Speech At The U.N. Climate Action Summit. New York. 23 September.

Thunberg, G., Hinchliffe, J., Ferreira de Assis, D., Peña Panichine, J., Jullian, R., Neubauer, L., Kangujam, L., Wicker, D., Haddad, J., Adenike, O., Badruddin, I., Makichyan, A., Gillibrand, H., Martínez, A., Axelsson, I., Axelsson, S., Jarl, E., Pohankova, S., Dolder, L., Nakate, V and Iron Eyes, T. (2020). At Davos We Will Tell World Leaders To Abandon The Fossil Fuel Economy. The Guardian. January 10. (https://www.theguardian.com/commentisfree/2020/jan/10/greta-thunberg-davostycoons-fossil-fuels-dismantle-climate-crisis)

Tiberj, V. (2017). Les citoyens qui viennent: Comment le renouvellement générationnel transforme la politique en France. Collection Le lien social. Paris : Presses Universitaires de France (PUF).

Tilly, C. (1986). The Contentious French. Cambridge MA: Harvard University Press.

Tilly, C. (1995). Popular Contention in Great Britain 1758-1934. Cambridge: Cambridge University Press.

Tilly, C. (2002). Stories, Identities and Political Change. Maryland: Rowman \& Littlefield. Tilly, C. (2003). The Politics of Collective Violence. Cambridge: Cambridge University Press. Townsend, M. (2019). Tube Protest was a Mistake, Admit Leading Extinction Rebellion Members. The Guardian. October 20. 
(https://www.theguardian.com/environment/2019/oct/20/extinction-rebellion-tubeprotest-was-a-mistake).

Tufekci, Z. (214). The Medium and the Movement: Digital Tools, Social Movement Politics and the End of the Free Rider Problem. Policy and Internet, pp. 202-208.

United Kingdom Student Climate Network (UKSCN). (2019). Welcome page. (https://ukscn.org).

Verick, S. (2010). Who is Hit Hardest during a Financial Crisis? The Vulnerability of Young Men and Women to Unemployment in an Economic Downturn. In: I. Islam and S. Verick, eds. From the Great Recession to Labour Market Recovery: Issues, Evidence and Policy Options. London: Palgrave Macmillan and International Labour Organization (ILO).

Wahlström, M., Kocyba, P., De Vydt, M., de Moor, J. (2019). Protest For A Future: Composition, Mobilization and Motives of The Participants in Fridays For Future Climate Protests on 15 March 2019 in 13 European Cities. (https://gup.ub.gu.se/publication/283193).

Wall, D. (1999). EarthFirst! and the Anti-roads Movement: Radical Environmentalism and Comparative Social Movements. London and New York: Routledge.

Wolf, J. and Moser, S. (2011). Individual Understandings, Perceptions, And Engagement With Climate Change: Insights From In-depth Studies Across The World: Individual Understandings, Perceptions, and Engagement with Climate Change. Wiley Interdisciplinary Reviews: Climate Change 2 (4), pp. 547-569.

YouGov. (2019). Which Of The Following Do You Think Are The Most Important Issues Facing The Country At This Time? YouGov survey results, 30-31 October. (https://d25d2506sfb94s.cloudfront.net/cumulus_uploads/document/rxpylj3uwa/Internal _Issues_191031_W.pdf). 
${ }^{1}$ RisingUp! was a network of activists in Britain, most of whom had been involved in other environmental and social justice protest networks previously.

${ }^{2}$ Both movements have based their demands on the United Nations Intergovernmental Panel on Climate Change (IPCC), Special Report: Global Warming of $1.5^{\circ} \mathrm{C}$, published in 2018 .

${ }^{3}$ Participants signed ethical consent forms prior to the start of interviews. For interviewees under the age of 16 , signed parental consent was obtained. Some participants gave pseudonyms.

${ }^{4}$ In Britain specifically, at the start of the twenty-first century, there was centre-left Labour government led by Prime Minister Tony Blair (1997-2007) and then Gordon Brown (2007-2010). The global financial crisis (2008) and the ensuing Great Recession had a significant impact on the economy and the population. The arrival of the centre-right Conservative - Liberal Democrat coalition government (2010-2015) represented a turning point with the implementation of significant austerity measures continued by subsequent Conservative governments (Cooper and Whyte, 2017) and the 2016 referendum on the United Kingdom's membership of the European Union resulting in 'Brexit.' (Ehsan and Sloam, 2020).

${ }^{5}$ The distinction between reformist and radical approaches provides a useful shorthand means of categorising two different ways of addressing environmental problems. Broadly speaking, reformists adopt "a managerial approach" to environmental problems, which they believe can be solved without major changes to our current political and economic structures. By way of contrast, advocates of radical positions contend that solutions to the environmental crisis rely on radical changes to our relationship with the non-human natural world as well as our political and economic structures (Dobson, 2000, see also Carter, 2018).

${ }^{6}$ One of the three main themes in the Hansard Society's annual Audit of Political Engagement in Britain for 2019 was "Appetite for radical political changes." It states: "People are pessimistic about the country's problems and their possible solution, with sizable numbers willing to entertain radical political changes" (Hansard Society, 2019).

${ }^{7}$ School strikes have been used by young activists across the world for various causes. In Britain, specifically, there were waves of school strikes connected to wider political upheaval and class conflict in 1889, 1911, 1972 and 1985 (Cunningham and Lavalette, 2004, p. 266).

${ }^{8}$ Radical environmental protest actions including violence and criminal damage have also been carried out in recent years elsewhere, for example, by "Zadistes" in France: anti-globalisation environmental activists that aim to prevent construction and development on a specific site, especially in rural areas, which activists deem a "Zone to Defend" ("Zone à défendre").

${ }^{9}$ It is noteworthy that these environmental protests took place during a period of Conservative governments (Prime Ministers Margaret Thatcher 1979-1990 and John Major 1990-1997). When young people were particularly hard hit by the unfavourable economic climate (see Pickard, 2019a).

${ }^{10}$ On 22 October 2019, at a press conference, the London Metropolitan Police Service (MPS) Commissioner Cressida Dick, said a total of 1,828 protesters were arrested in October 2019, of whom 164 had been charged thus far. She went on to state that in April 2019, 1,148 activists were detained with more than 900 charged, most receiving a conditional discharge. According to the London Metropolitan Police Service (MPS), the Extinction Rebellion October 2019 protests cost the police force $£ 24$ million (BBC, 2019).

${ }^{11}$ Ian Bray (51) spray painted outside walls broke glass panels of UK Shell headquarters in London in April 2019 and was arrested. In an interview with one of the authors in September 2019, he claimed he was more frightened about the climate crisis than going to prison and that the ecological breakdown was more important than being arrested. Similarly, during the Extinction Rebellion 'International Rebellion' fortnight, on 15 October 2019, Gail Bradbrook (47) damaged bullet-proof glass panel at the entrance of the Department of Transport building in London and was arrested. 